\title{
Factors that create Obstacles and Opportunity for Patient Participation in Orthopaedic Nursing Care
}

\section{The nurse plays an essential role in enabling the patient's sense of participation, but patient's involvement is essential and wound healing often requires patient involvement. The aim of this study was to highlight factors that hinder patient care and provide opportunities for patient- centred care from a nursing perspective.}

\section{ABSTRACT \\ Background}

The nurse plays an essential role in enabling the patient's sense of participation. Although it has been several years since patient law was enacted, the patient's involvement in their own care is still poorly understood in several areas. In many areas, wounds occur in various forms. Wound healing often requires patient involvement.

\section{Aim}

The aim of this study was to highlight factors that hinder patient care and provide opportunities for patient participation in orthopaedic care from a nursing perspective.

\section{Methods}

Electronic databases, such as PubMed and Cinahl, were searched using keywords from 2007-2017. Fifteen articles were reviewed, both qualitatively and quantitatively, and included in the content analysis.

\section{Results}

Our results show the importance of open communication between nurses and patients, the routine and working methods used in healthcare facilities, as well as the fact that an organisation which supports a working person-centred approach is needed. Nurses and all members of the team need time for reflection and guidance to accomplish the personcentred approach.

\section{Conclusions}

Person-centred care needs a new mindset to allow the patient to play a more active role. Skills and in- dividual training in groups are needed. To increase patient participation through person-centred care, organisational change and the resultant development of new routines are also important. This approach to healthcare can also reduce stress.

\section{Implications for Clinical Practice}

A participating patient can lead to faster recovery, higher quality of life, lower cost, and higher quality for health care. To achieve this, active leadership, a positive attitude from staff, encouragement, and support are needed for the patient. The work environment should be reviewed because it affects everyone in the healthcare sector.

\section{BACKGROUND}

Today patients have higher demands to participation in and influence healthcare. Access to information and the opportunity to express their expectations before a scheduled operation have been shown to produce a more realistic expectation of patient experience and self-reported health. ${ }^{1,2}$ As we live longer, the cost of healthcare increases. Complicated operations can now be performed on ill, elderly, or physically weak patients. The care period in the hospital is short and day surgery is often possible. For example, five to ten years ago in Sweden, it was standard for patients undergoing knee replacement surgery to stay in the hospital for seven to ten days. Today, some patients can recover at home starting the day after this type of surgery. These developments place greater demands on the nurses and the multidisciplinary

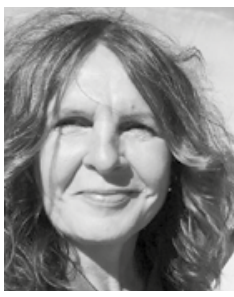

Susanne Stålenhag $\mathrm{RN}, \mathrm{BSc}$, Trauma and Reparative Medicine Theme, Karolinska University Hospital. Stockholm, Sweden.

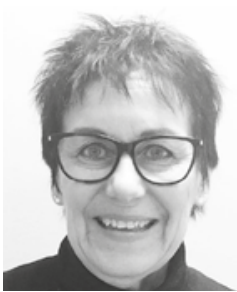

Eila Sterner $\mathrm{RN}, \mathrm{PhD}$, Head of nursing development, Inst. Molecular medicine and surgery, Trauma and Reparative Medicine Theme, Karolinska University Hospital. Stockholm, Sweden.
Correspondence: susanne.stalenhag@sll.se Conflicts of Interest: None 
team. Once home the patient's task is to watch over the wound. They need to know when to contact their healthcare team if something is not right, such as when they have a fever, the wound dressing leaks, they notice a smell, or when other problems related to the wound occur.

Nursing involves both surgical and non-surgical care. Excellent nursing requires theoretical knowledge and an ability to perform with an ethical approach. ${ }^{3}$ The patient is a specialist in his/herself and a valuable resource, but they do not always feel like an equal partner in their own healthcare. ${ }^{4}$ They are entitled to, and responsible for, decisions that concern their own lives. The nurse can both facilitate the healing process and support the patient in increasing the feeling of well-being that can lead to an improved quality of life. . $^{5}$

For patients to become more involved in their wellness, they need information, support, and knowledge about medical treatments. Laws and regulations shape healthcare in Sweden just as in other countries. Swedish law states that health and medical care must be conducted in such a way that it meets the requirements for good care and that it must be based on respect for the patient's self-determination and integrity. ${ }^{9-11}$ Systematic quality work must also be performed in paralle ${ }^{12}$ to continuously develop and secure the quality of care. However, the goal of achieving high quality patient-centred care has proven difficult.

\section{Participation}

Patient participation is a vague and ambiguous concept. The nurse plays a crucial role in encouraging and engaging the patient, which in turn increases his or her self-esteem. ${ }^{13}$ To achieve this goal, collaboration based on communication and understanding of the situation is required. ${ }^{14}$ Health and medical care have evolved from being traditional and paternalistic to starting from the patient's personal preferences. ${ }^{15}$ If the nurse has a positive attitude plus gives encouragement and support to the patient, it is of great importance for participation and patient safety. ${ }^{2}$ Being seen is of great importance to the patient's sense of participation. ${ }^{16}$ Patients are often satisfied with the treatment, but less satisfied with information and participation. A well-informed and engaged patient is more likely to follow treatment plans and experience increased well-being. ${ }^{13}$

A person-centred approach requires participation from the whole healthcare team. Person-centred care also requires becoming familiar with another person's perspective, and the ability to adapt working methods based on the patient's needs and wishes. For the nurse, this means having a holistic perspective, being honest and committed, and willing to show respect for the individual patient's story. ${ }^{3}$
It is important to ask patients open-ended questions, listen carefully, and allow time for the patient to express himself. 2,15,17 Improved communication, individualised care, shared decision-making, and patient education are other factors that lead to increased patient involvement and independence. ${ }^{15}$

In one of the first literature reviews on person-centred care, person-centring is defined as an approach with four central concepts: being in a relationship, being in a social world, being in a place, and being yourself. ${ }^{18}$ Within personcentred care, the perspective is shifted from describing "what" a patient is about to telling "who" a person is based on three parts: the patient's story, forming a partnership (i.e., the team's collective knowledge of the patient), and having a documented planned agreement. ${ }^{19}$ Placing the patient as the focal point, which is based on relationships and the need for a patient story, is actually not a new concept; one can read it already in Travelbee's interaction theory. ${ }^{20}$ Communication between nurse and patient is fundamental to good care. There are several touch points between Travelbee's theory and person-centred care. She describes it as essential that all people have equal value, and that one should see each patient as a human being and not someone who is "sick." With person-centred care, nurses are aware that suffering is subjective. Regardless of the disease or diagnosis, the patient may experience illness differently, and the experience of health-related illness is therefore unique. The patient is always at the centre and it is important to build a relationship from the beginning to meet the patient's needs. Travelbee and person-centred care are thus aligned on the need for the patient story. The nurse must be committed to taking the time to understand the needs of the patient. An important part of nursing care is effective communication to increase the interaction between nurse and patient. ${ }^{20}$

The key to following and finding meaning in the patient's story is understanding both verbal and non-verbal communication. ${ }^{21}$ All people are unique and have the right to good health regardless of their abilities and resources. Therefore, it is essential to study the obstacles and opportunities that can affect the patient's involvement from a nursing perspective in the field of orthopaedics.

\section{METHODS}

Student papers can make differences and contribute to the implementation of more in-depth research within the chosen area. To cover the current research field, online databases such as PubMed and Cinahl were used. Both qualitative and quantitative research were included in the content analysis ${ }^{22}$ to help answer the research question. Research articles in languages other than English 
and Swedish were excluded due to translation issues. The search strategy did not impose any language limitations.

\section{Data Gathering}

The literature research began with a manual search strategy to obtain an understanding of the current area. The review question was identified using keywords and a combination of keywords with AND, OR, and NOT. The keywords Patient participation, Patient-centred care, Nurse-patient relations, Nurse's role, and Orthopaedics were combined with Communication barriers and obstacles. The search was conducted with the consultation of an expert librarian, and papers published from 2007 to 2017 were collected. The search strategy and results of different phases and combinations of the systematic review are presented in Tables 1 and 2 .

Inclusion criteria were focused on articles where the survey group consisted of people over 18 years of age and when patient engagement was combined with orthopaedic care and nursing involvement. Unfortunately, orthopaedic care did not give any relevant results, so the search was broad- ened to acute care. Each phase of the systematic review was conducted by the author. The first step involved selecting the papers to include in the review. The second step was appraising the methodological quality of the included papers followed by extracting data from the papers. Finally, a synthesis of the papers was prepared for presenting the findings. These different steps were described in the literature by Caldwell. ${ }^{22}$ The articles were checked for quality using criteria developed on a scorecard as published previously. ${ }^{23,24}$ Fifteen papers met the quality criteria and were included in the final analysis.

\section{ANALYSIS}

To create the summary, the selected articles were tabulated to facilitate overview and formulate conclusions. ${ }^{22,25}$ Data were classified, and significant information was marked in color to organise the data into groups. Then the similarities and differences were identified and grouped into different themes, categories, and codes. ${ }^{22,25}$ Two themes were identified: obstacles and opportunities for patient participation. Three categories were identified: communication between the nurse and patient, working methods

Table I. Summary of search strategies used in this review.

Search strategies using databases such as PubMed and CIHNAL, keywords and their combinations are listed.

\begin{tabular}{|c|c|c|c|c|}
\hline $\begin{array}{l}\text { DATABASE } \\
\text { DATE }\end{array}$ & $\begin{array}{l}\text { KEYWORDS } \\
\text { AND COMBINATIONS }\end{array}$ & HITS & $\begin{array}{l}\text { ABSTRACTS } \\
\text { READ }\end{array}$ & $\begin{array}{l}\text { ARTICLE(S) } \\
\text { INCLUDED }\end{array}$ \\
\hline $\begin{array}{l}\text { PubMed } \\
171129\end{array}$ & $\begin{array}{l}\text { Patient Participation and Patient-Centred Care } \\
\text { AND Nurse-Patient Relations AND/OR Nurse's } \\
\text { Role }\end{array}$ & 99 & 20 & 7 \\
\hline $\begin{array}{l}\text { PubMed } \\
171129\end{array}$ & $\begin{array}{l}\text { Patient Participation AND Patient-Centred Care } \\
\text { AND Nurse's Role }\end{array}$ & 88 & 10 & 0 \\
\hline $\begin{array}{l}\text { PubMed } \\
171129\end{array}$ & $\begin{array}{l}\text { Patient Participation and Patient-Centred Care } \\
\text { AND Nurse-Patient Relations AND/OR Nurse's } \\
\text { Role AND/OR Communication Barriers AND/ } \\
\text { OR Hinders }\end{array}$ & 25 & 4 & 1 \\
\hline $\begin{array}{l}\text { CIHNAL } \\
171205\end{array}$ & Participation and Orthopaedics and Patient & $\begin{array}{l}127(126 \\
\text { unique) }\end{array}$ & 10 & $\begin{array}{l}\text { ( } 1 \text { - same as } \\
\text { in Pubmed) }\end{array}$ \\
\hline $\begin{array}{l}\text { CIHNAL } \\
171205\end{array}$ & Participation and Person-Centred and Patient & $\begin{array}{l}82(80 \\
\text { unique) }\end{array}$ & 10 & $\begin{array}{l}\text { (2 - same as } \\
\text { n PubMed) }\end{array}$ \\
\hline $\begin{array}{l}\text { CIHNAL } \\
171206\end{array}$ & Participation or Person-Centred or Nurse & $\begin{array}{l}26(24 \\
\text { unique) }\end{array}$ & 5 & $\begin{array}{l}\text { (2 - same as } \\
\text { in PubMed) }\end{array}$ \\
\hline \multicolumn{2}{|c|}{$\begin{array}{l}\text { Manual Search and Articles from } \\
\text { Supervisor and Colleagues }\end{array}$} & 7 & & 7 \\
\hline Total & & 454 (449) & 66 & 15 \\
\hline
\end{tabular}


Table 2. Strategy employed to select the 15 articles reviewed for this study.

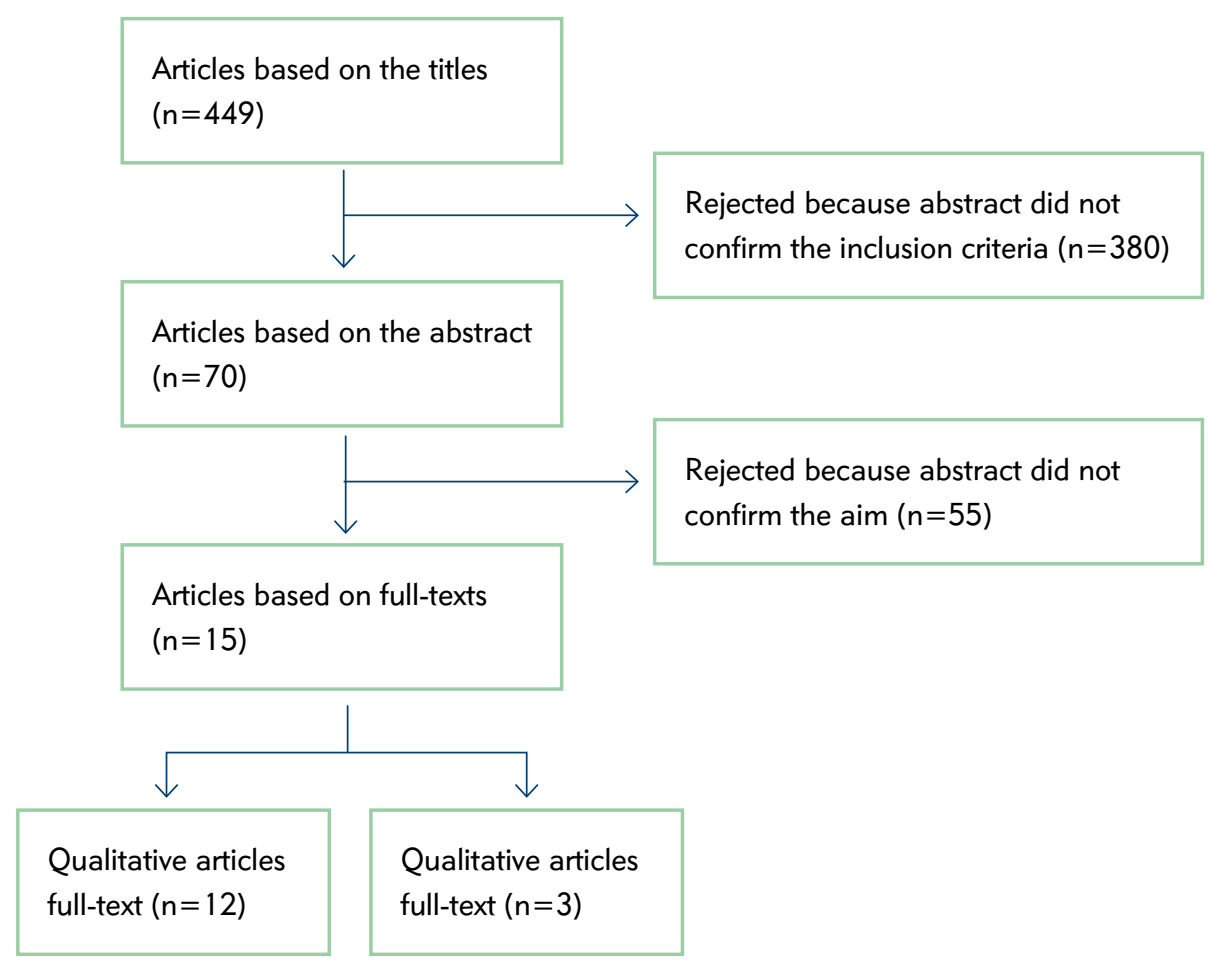

and routines in the healthcare unit, as well as obstacles and opportunities for patient participation from an organisational perspective. (See Table 3).

\section{RESULTS}

Obstacles - Communication Between the Nurse and Patient

There was less communication with the patient when nurses did their work without involving the patient. The nurses wish to have more control over how the work should be performed with no interference, and thus, would rather provide care themselves instead of involving, instructing, or educating the patient. ${ }^{26}$ This way of working depends on the professional judgment and confidence of the nurse who is responsible for the patient's health and safety. Thus, patient safety must be the top priority if rules are overridden so that patients can participate more actively in their own care. ${ }^{26,27}$ Other factors that affect communication include the patient's cognition, cultural background, and language barriers. ${ }^{28}$

Lack of teamwork, large workload, and stress also reduced the patient's ability to participate. Speaking above the patient's comprehension can make the patient feel invisible. ${ }^{28}$ The same feeling of invisibility can arise if there is a computer screen located between the patient and nurse. ${ }^{29} \mathrm{Be}-$ ing informed is not the same as being involved. However, some patients see themselves as passive listeners. ${ }^{30}$ and may adopt a more traditional, compliant role as it may be a more convenient way for them to relate. ${ }^{29}$ This response might be due to a lack of understanding of how to invite them into the conversation and increase their confidence. ${ }^{29}$

\section{Obstacles - Routine}

The nurse usually worked routinely, especially on days with higher stress. ${ }^{26}$ Furthermore, today's system of rounds does not encourage teamwork or interprofessional communication, which leads to frustration and reduced nursing quality. ${ }^{31}$ For example, even though nurses wanted to invite patients to take care of their usual medication, the nurses felt bound to rules and regulations for fear that something would go wrong and affect patient safety. ${ }^{26}$, 27 Documentation was rarely collected together with the patient, which resulted in incomplete recordkeeping that did not describe the patient's desires and needs. ${ }^{32}$

\section{Obstacles - Organisation}

The advantage of person-centred care is perceived differently by different occupational categories. The physician observed little value in the need to implement a personcentred approach compared to other healthcare staff. They considered person-centred care as belonging to nursing and not medical care. ${ }^{33,34}$ The culture of an organisation has a significant impact on the implementation of personcentred care. The care is often controlled by production agreements, which can be affected when working toward person-centred care because it takes time to listen to the patient's story. ${ }^{35}$ Implementation of person-centred care in a workplace is also affected by high staff turnover, the 
Table. 3. Description of the data analysis themes, categories, and codes based on the 15 papers reviewed.

\begin{tabular}{|c|c|c|}
\hline THEME & CATEGORY & CODE \\
\hline \multirow[t]{3}{*}{$\begin{array}{l}\text { Obstacles to patient } \\
\text { participation }\end{array}$} & $\begin{array}{l}\text { Obstacles to communication between the nurse } \\
\text { and the patient - for patient participation }\end{array}$ & $\begin{array}{l}\text { The relationship between nurse and patient } \\
\text { The importance of communication } \\
\text { Passivity of the patient } \\
\text { Attitudes } \\
\text { Cultural factors for nurses and patients }\end{array}$ \\
\hline & $\begin{array}{l}\text { Obstacles to working methods and routines in } \\
\text { the healthcare unit - for patient participation }\end{array}$ & $\begin{array}{l}\text { Routines } \\
\text { Standardisation } \\
\text { Patient safety } \\
\text { Secrecy } \\
\text { Documentation }\end{array}$ \\
\hline & $\begin{array}{l}\text { Obstacles from an organisational perspective - } \\
\text { for patient participation }\end{array}$ & $\begin{array}{l}\text { Skills shortage (knowledge) } \\
\text { Difficulties with implementation } \\
\text { Lack of team work } \\
\text { Jargon } \\
\text { Leadership } \\
\text { Hierarchical structures } \\
\text { Stress } \\
\text { High workload } \\
\text { High staff turnover } \\
\text { Inexperienced nurses }\end{array}$ \\
\hline \multirow[t]{3}{*}{$\begin{array}{l}\text { Opportunities for patient } \\
\text { participation }\end{array}$} & $\begin{array}{l}\text { Communication between the nurse and the } \\
\text { patient that can support }\end{array}$ & $\begin{array}{l}\text { Commitment } \\
\text { Communication } \\
\text { Attitudes } \\
\text { Autonomy } \\
\text { Empowerment }\end{array}$ \\
\hline & $\begin{array}{l}\text { Working methods and routines in the health- } \\
\text { care unit - that can support patient participa- } \\
\text { tion }\end{array}$ & $\begin{array}{l}\text { Partnerships } \\
\text { Person-centred care } \\
\text { Rounds } \\
\text { Reports (between shifts, patient records) } \\
\text { Documentation }\end{array}$ \\
\hline & $\begin{array}{l}\text { From an organisational perspective - to support } \\
\text { patient participation }\end{array}$ & $\begin{array}{l}\text { Teamwork } \\
\text { Interprofessional work } \\
\text { Leadership } \\
\text { Organisation } \\
\text { Reflection } \\
\text { Learn from each other } \\
\text { Training }\end{array}$ \\
\hline
\end{tabular}

hiring of nurses without person-centred care experience, lack of experience in the staff overall, as well as a stressful work environment. ${ }^{36}$ The existing paternalistic healthcare system requires educational skills when implementing a patient-centred care approach where patients are seen as partners. ${ }^{35}$

\section{Possibilities - Communication}

The nurse plays a crucial role in promoting the patient's opportunity to participate in their care. ${ }^{36}$ At the same time, this is a challenging task. The nurse must identify each patient's specific needs and a find balance between assessing the patient's condition and the need for nursing. Studies show that when the nurse asks open-ended questions and inquires about the current situation, the patient's ability to participate actively in their care is encouraged and strengthened. ${ }^{37}$ By deliberately handing over responsibilities in various nursing activities, the patient feels encouraged to understand, participate in, and increase their 
commitment to healing. ${ }^{28,29}$ When professionals listened to the patient and focused on them as a person rather than on their disease, they felt secure. ${ }^{29}$ Listening to the patient is also an attribute that demonstrates empathy by the nurse. Patients experienced something more than just being taken care of; they experienced hope, which, in turn, created a catalyst for empowerment and participation. ${ }^{38}$ Listening and encouraging participation without the patient feeling pressure to take a decision is a winning concept. ${ }^{39}$ When the patient's role is strengthened with increased participation, improved patient safety is observed, leading to independence and confidence. ${ }^{36}$

\section{Possibilities - Routine}

The interaction between a patient and their nurse increases the patient's sense of participation and leads to safer care. Patients who felt they were treated respectfully were more willing to speak up and felt that they could correct any inaccuracies, leading to increased patient safety. ${ }^{27,30}$ Having time for reflection and supervision also plays an important role in the nurses' ability to implement person-centred. ${ }^{34}$

Patient-centred rounds have a positive impact on the nurses' work situation and have contributed to better teamwork and reduced hierarchy between different healthcare professionals. ${ }^{31}$ When working in a person-centred environment, documentation is performed together with the patient and their relatives, which prevents misunderstandings and clarifies communication. ${ }^{32}$

\section{Possibilities - Organisation}

The development of nursing skills in communication strategies and person-centred care as a measure of patient safety would promote patient participation. ${ }^{26}$ However, attention should be paid to nurses' concerns about maintaining confidentiality in connection with the patient. ${ }^{30}$

The workplace culture, (i.e., the employees' perception of methods, procedures, and behaviours) affects patient participation. The need for a strong relationship between the work environment and person-centred care has been presented. ${ }^{40} \mathrm{~A}$ positive workplace culture is a prerequisite for person-centred care and, thus, patient participation. Nurses should have opportunities to continue their education, so that they can further develop their skills. The work environment affects both the nurses' commitment and motivation, especially in times when a full workload is carried. ${ }^{40}$

\section{DISCUSSION}

Open communication between everyone on the patient's team (including the patient themselves) is an essential suc- cess factor in achieving a person-centred approach. The review of work routines is required to increase active participation by the patient. The nurses felt bound to rules and regulations. Nurses should not fear scrutiny if rules are overridden or routines changed when the patient participates more actively. ${ }^{26,27}$

Orthopaedics was a criterion included in our database searches. Unfortunately, this term did not provide any relevant hits together with or without the wound healing process. This finding reveals that patient involvement in orthopaedic nursing care could be interesting to study. The literature review method was chosen for this bachelor's thesis to obtain more knowledge about the field of patient-centred care and to facilitate planning of follow-up studies at a later stage. Literature review with a systematic approach gives readers the opportunity to decide whether the conclusions are credible.

This literature review has both strengths and weaknesses. One of the strengths was that nine of the 15 selected articles were written after 2013, which should increase the reliability of the results obtained. A possible weakness is that this review was written by only one author which, due to a lack of collaboration, may limit processing of the collected material and the opportunity to include all papers in the review. One's understanding can also affect and shape the outcome. It is difficult to generalise the results presented in this paper, but it can be used as a basis for discussion in one's healthcare unit. Writing a review also requires different biases to be considered. For example, the studies discussed in these articles were performed in different countries, six from Sweden, five from Australia, one from Canada, USA, and Ireland, and one from Israel. Thus, further discussion could be conducted about whether the healthcare systems in these countries differs and how any differences may affect the results.

The concept of person-centred care is based on the patient being an equal partner. This partnership is only achieved if the patient is invited to participate and is given the opportunity to influence their own care. The intention is not for the staff to create something for the patient. Instead the staff should identify and strengthen the resources that exist in the patient. ${ }^{19}$ Participation, the patient's autonomy, communication, and the role of the nurse are the basis for person-centred care, which in turn leads to patient involvement. There may be different perceptions between the patient and the nurse regarding the extent of participation, and this may be the reason why the patient sometimes feels dissatisfied with the nursing care received. ${ }^{4}$ 
The department's routines and the nurse's attitude, communication, and sometimes controlling function reduce the patient's ability to participate. ${ }^{26,41}$ Existing routines and the absence of them can both impede a patient's willingness to participate. ${ }^{26,41,42}$ Short care times and a shortage of experienced staff can make it difficult to provide individualized care as it is easier to follow standard routines. Today's rounds system can also prevent patient participation. ${ }^{31}$ The difficulty of nurses handling confidentiality and sharing confidential information during bedside conversation was highlighted in several articles. ${ }^{28,}$ 30,41 At the same time, conducting bedside conversation provides opportunity to amend any inaccuracies in the patient information. ${ }^{30}$ This could be remedied by providing more private rooms in the healthcare units and changing work methods.

Lack of experienced staff, continuity, and a large workload can lead to less patient participation. ${ }^{36,39}$ One study also observed that time restrictions limit the possibility of patient participation, which ultimately affects patient safety. ${ }^{42}$ The same study also showed that the patient's respect for authority can serve as an obstacle to many patients' involvement in their care and treatment. Involving the patient at a round creates opportunities for improved communication, teamwork, and reduced hierarchy. ${ }^{31}$

Creating opportunities within the healthcare organisation for professionals to work toward a person-centred approach by educating nurses in communication strategies will promote participation. ${ }^{26}$ Discussing person-centred care at all levels of the organisation as a measure of patient safety ${ }^{30}$ can be a winning concept for increased participation and opportunities. The importance of partnership and competent staff in creating security, and therefore patient participation, is important. ${ }^{39}$ An educational, supportive working model with reflection and supervision is a prerequisite for nurses to implement new approaches for increased patient participation. ${ }^{37}$

\section{CONCLUSION}

Person-centred care requires a new mindset to let the patient play a more active role. There are many factors that influence the opportunity for patient participation in daily care, from the healthcare organisation in the ward and its leadership to the work environment for nurses in the healthcare sector. Both verbal and non-verbal communication between patients and nurses are as important as communication between all healthcare professionals. However, the fear that nurses feel when overriding rules or adjusting routines to allow patients to participate can hinder person-centred care from being fully implemented.

This student essay can make a difference by helping to elucidate the fact that in-depth research is needed within a specific area of orthopaedic patient care. It also shows the importance of taking a critical approach when evaluating published studies. Equally important is the fact that care must rest on the best scientific research available. Wounds are treated in all fields of healthcare, especially in orthopaedic care. It is not only surgical wounds but also hardto-heal wounds after trauma and infections. Diabetic foot ulcers also occur. Those in need of wound healing are both young and old. Because wounds and people vary greatly, it is even more important to find working methods that involve the patient in an optimal and natural way. The wound healing process often requires patient involvement. They need to know when to contact their healthcare team if something is not right with the healing process.

Table 4/1. Framework for the review, including quality control.

\begin{tabular}{|c|c|c|c|c|c|}
\hline $\begin{array}{l}\text { AUTHORS } \\
\text { YEAR } \\
\text { COUNTRY }\end{array}$ & AIM & TITLE & METHODS & RESULTS & $\begin{array}{l}\text { QUALITY/ } \\
\text { TYPE OF } \\
\text { STUDY }\end{array}$ \\
\hline $\begin{array}{l}\text { Tobiano, Bucknall, } \\
\text { Marshall, Guinane, } \\
\text { Chaboyer } \\
2015 \\
\text { Australia }\end{array}$ & $\begin{array}{l}\text { To explore nurses' } \\
\text { views on patient } \\
\text { participation in nursing } \\
\text { care. The objectives } \\
\text { of this study were to } \\
\text { investigate nurses' un- } \\
\text { derstanding of patient } \\
\text { participation, and the } \\
\text { barriers and facilitators } \\
\text { to it. }\end{array}$ & $\begin{array}{l}\text { Nurses' view of } \\
\text { patient participating } \\
\text { in nursing care }\end{array}$ & $\begin{array}{l}\text { Interpretive study } \\
\text { In-depth semi- } \\
\text { structured interviews } \\
\text { were conducted and } \\
\text { analysed using content } \\
\text { analysis. }\end{array}$ & $\begin{array}{l}\text { Five categories emerged } \\
\text { from the nurses' views. } \\
\text { Nurses play a crucial role in } \\
\text { promoting patient participa- } \\
\text { tion. Nurses felt limited by } \\
\text { rules, perceptions of main- } \\
\text { taining safety, and patient } \\
\text { characteristics when attempt- } \\
\text { ing to enact participation. }\end{array}$ & $\mathrm{I} / \mathrm{K}$ \\
\hline
\end{tabular}


Table 4/1. Framework for the review, including quality control.

\begin{tabular}{|c|c|c|c|c|c|}
\hline $\begin{array}{l}\text { AUTHORS } \\
\text { YEAR } \\
\text { COUNTRY }\end{array}$ & AIM & TITLE & METHODS & RESULTS & $\begin{array}{l}\text { OUALITY/ } \\
\text { TYPE OF } \\
\text { STUDY }\end{array}$ \\
\hline $\begin{array}{l}\text { Svanström, } \\
\text { Andersson, Rosén, } \\
\text { Berglund } \\
2016 \\
\text { Sverige }\end{array}$ & $\begin{array}{l}\text { To describe experi- } \\
\text { ences of implementing } \\
\text { a process based on a } \\
\text { learning support model } \\
\text { designed to increase } \\
\text { patient involvement } \\
\text { and autonomy in care. }\end{array}$ & $\begin{array}{l}\text { Moving from theory } \\
\text { to practice: experi- } \\
\text { ence of implementing } \\
\text { a learning support } \\
\text { model designed } \\
\text { to increase patient } \\
\text { involvement and } \\
\text { autonomy in care }\end{array}$ & $\begin{array}{l}\text { Data were collected } \\
\text { through interviews, } \\
\text { notes, and written } \\
\text { stories, and then ana- } \\
\text { lysed using herme- } \\
\text { neutic analysis with a } \\
\text { focus on meanings. }\end{array}$ & $\begin{array}{l}\text { The participants described } \\
\text { challenges when patients } \\
\text { became involved in their } \\
\text { care and took charge of } \\
\text { their lives. The participants' } \\
\text { experience led to increased } \\
\text { self-confidence and feelings } \\
\text { of improved competence in } \\
\text { dialogue with patients. }\end{array}$ & $\mathrm{I} / \mathrm{K}$ \\
\hline $\begin{array}{l}\text { Sharp, McAllister, } \\
\text { Broadbent } \\
2016 \\
\text { Australia }\end{array}$ & $\begin{array}{l}\text { To examine and } \\
\text { understand the } \\
\text { unique and particular } \\
\text { experiences of a group } \\
\text { of former patients' } \\
\text { participating in person- } \\
\text { centred care. }\end{array}$ & $\begin{array}{l}\text { The vital blend of } \\
\text { clinical competence } \\
\text { and compassion: how } \\
\text { patients experience } \\
\text { person-centred care }\end{array}$ & $\begin{array}{l}\text { Semi-structured in- } \\
\text { terviews with patients } \\
\text { were examined via } \\
\text { thematic analysis } \\
\text { to understand how } \\
\text { patients identify ways } \\
\text { to enhance and sup- } \\
\text { port compassionate } \\
\text { person-centred care } \\
\text { in everyday nursing } \\
\text { practice. }\end{array}$ & $\begin{array}{l}\text { Clinically competent care, } \\
\text { delivered compassionately } \\
\text { through a positive nurse- } \\
\text { patient relationship, resulted } \\
\text { in personal, emotional, } \\
\text { or spiritual responses that } \\
\text { were the catalyst for patient } \\
\text { empowerment and participa- } \\
\text { tion in care, and a positive } \\
\text { outlook toward recovery. }\end{array}$ & $\mathrm{II} / \mathrm{K}$ \\
\hline $\begin{array}{l}\text { Abdelhadi, Drach- } \\
\text { Zahavy } \\
2011 \\
\text { Israel }\end{array}$ & $\begin{array}{l}\text { To test a model that } \\
\text { suggests the ward's } \\
\text { climate of service } \\
\text { facilitates nurses' } \\
\text { patient-centred care } \\
\text { behaviours through } \\
\text { its effect on nurses' } \\
\text { engagement. }\end{array}$ & $\begin{array}{l}\text { Promoting patient } \\
\text { care: work engage- } \\
\text { ment as a mediator } \\
\text { between ward service } \\
\text { climate and patient- } \\
\text { centred care }\end{array}$ & $\begin{array}{l}\text { A nested cross- } \\
\text { sectional research } \\
\text { design was adopted, } \\
\text { with three parameters } \\
\text { to measure the be- } \\
\text { haviour of nurses by } \\
\text { questionnaires: work } \\
\text { engagement, ward's } \\
\text { climate for service, } \\
\text { and control variables. } \\
\text { Patient-centred care } \\
\text { behaviours were as- } \\
\text { sessed by structured } \\
\text { observations. }\end{array}$ & $\begin{array}{l}\text { The findings: service climate } \\
\text { proved to be a link to nurses' } \\
\text { work engagement and } \\
\text { patient-centred care behav- } \\
\text { iours. Nurses' work engage- } \\
\text { ment mediated the service } \\
\text { climate patient-centred care } \\
\text { behaviours. }\end{array}$ & II/RCT \\
\hline $\begin{array}{l}\text { Alharbi, Carlström, } \\
\text { Ekman, Jarneborn, } \\
\text { Olsson } \\
2014 \\
\text { Sweden }\end{array}$ & $\begin{array}{l}\text { To investigate whether } \\
\text { patients did in fact } \\
\text { perceive the intentions } \\
\text { of partnership in the } \\
\text { new care model } 1 \text { year } \\
\text { after its implementa- } \\
\text { tion. }\end{array}$ & $\begin{array}{l}\text { Experiences of } \\
\text { person-centred care- } \\
\text { patients' perceptions: } \\
\text { qualitative study }\end{array}$ & $\begin{array}{l}\text { Sixteen participants } \\
\text { were interviewed. }\end{array}$ & $\begin{array}{l}\text { Patients felt listened to and } \\
\text { that their own perception of } \\
\text { the situation had been noted. } \\
\text { Patients expressed that they } \\
\text { felt the staff saw them as } \\
\text { persons and did not solely } \\
\text { focus on their disease. }\end{array}$ & $\mathrm{I} / \mathrm{K}$ \\
\hline $\begin{array}{l}\text { Bolster, Manias } \\
2010 \\
\text { Australia }\end{array}$ & $\begin{array}{l}\text { To examine how } \\
\text { nurses and patients } \\
\text { interact with each oth- } \\
\text { er during medication } \\
\text { activities in an acute } \\
\text { care environment with } \\
\text { an underlying philoso- } \\
\text { phy of person-centred } \\
\text { care. }\end{array}$ & $\begin{array}{l}\text { Person-centred } \\
\text { interactions between } \\
\text { nurses and patients } \\
\text { during medication } \\
\text { activities in an acute } \\
\text { hospital setting: quali- } \\
\text { tative observation and } \\
\text { interview study }\end{array}$ & $\begin{array}{l}\text { A qualitative ap- } \\
\text { proach was used } \\
\text { comprising natu- } \\
\text { ralistic observations } \\
\text { and semi-structured } \\
\text { interviews. }\end{array}$ & $\begin{array}{l}\text { The results of the study } \\
\text { generated insights into } \\
\text { the nature of interactions } \\
\text { between nurses and patients } \\
\text { where person-centred care } \\
\text { is the underlying philosophy } \\
\text { of care. Three major themes } \\
\text { were found: provision of } \\
\text { individualised care, patient } \\
\text { participation, and contextual } \\
\text { barriers to providing person- } \\
\text { centred care. }\end{array}$ & $\mathrm{I} / \mathrm{K}$ \\
\hline
\end{tabular}


Table 4/2. Framework for the review, including quality control.

\begin{tabular}{|c|c|c|c|c|c|}
\hline $\begin{array}{l}\text { AUTHORS } \\
\text { YEAR } \\
\text { COUNTRY }\end{array}$ & AIM & TITLE & METHODS & RESULTS & $\begin{array}{l}\text { QUALITY/ } \\
\text { TYPE OF } \\
\text { STUDY }\end{array}$ \\
\hline $\begin{array}{l}\text { Jangland, Gun- } \\
\text { ningberg } \\
2017 \\
\text { Sweden }\end{array}$ & $\begin{array}{l}\text { To evaluate the imple- } \\
\text { mentation of a project } \\
\text { on patient participa- } \\
\text { tion, using two specific } \\
\text { research questions for } \\
\text { patients and nurses. }\end{array}$ & $\begin{array}{l}\text { Improving patient } \\
\text { participation in a } \\
\text { challenging context: } \\
\text { a } 2 \text {-year evaluation } \\
\text { study of an implemen- } \\
\text { tation project }\end{array}$ & $\begin{array}{l}\text { Study is a descriptive } \\
\text { design using quantita- } \\
\text { tive and qualitative } \\
\text { methods. }\end{array}$ & $\begin{array}{l}\text { Improving patient participa- } \\
\text { tion in a busy environment is } \\
\text { challenging. } \\
\text { Although the long-term } \\
\text { implementation project } \\
\text { did not improve patient } \\
\text { participation in the units, the } \\
\text { nurse managers described } \\
\text { a changing culture in which } \\
\text { staff grew to accept patients' } \\
\text { involvement in their own } \\
\text { care. Several barriers to } \\
\text { change and sustainability } \\
\text { were acknowledged. }\end{array}$ & I/RTC \\
\hline $\begin{array}{l}\text { Tobiano, Marshall, } \\
\text { Bucknall } \\
2016 \\
\text { Australia }\end{array}$ & $\begin{array}{l}\text { To describe and under- } \\
\text { stand the activities that } \\
\text { patients and nurses } \\
\text { undertake to enact } \\
\text { patient participation in } \\
\text { nursing care. }\end{array}$ & $\begin{array}{l}\text { Activities Patient and } \\
\text { Nurses Undertake } \\
\text { to Promote Patient } \\
\text { Participation }\end{array}$ & $\begin{array}{l}\text { Field notes were col- } \\
\text { lected and were ana- } \\
\text { lysed both inductively } \\
\text { and deductively. }\end{array}$ & $\begin{array}{l}\text { Nurse-patient interactions } \\
\text { promoted patient participa- } \\
\text { tion through dialogue and } \\
\text { knowledge sharing. Less } \\
\text { evident was patient involve- } \\
\text { ment in planning or self-care. } \\
\text { Nurses exerted control over } \\
\text { patient care, which } \\
\text { influenced the extent of } \\
\text { patient participation. }\end{array}$ & $\mathrm{II} / \mathrm{K}$ \\
\hline $\begin{array}{l}\text { Oxelmark, Ulin, } \\
\text { Chaboyer, Bucknall, } \\
\text { Ringdal } \\
2017 \\
\text { Sweden }\end{array}$ & $\begin{array}{l}\text { To describe registered } \\
\text { nurses' experiences } \\
\text { with patient participa- } \\
\text { tion in nursing care, } \\
\text { including their barriers } \\
\text { and facilitators for } \\
\text { participation. }\end{array}$ & $\begin{array}{l}\text { Registered Nurses' } \\
\text { experiences of patient } \\
\text { participation in hos- } \\
\text { pital care: supporting } \\
\text { and hindering factors } \\
\text { patient participation } \\
\text { in care }\end{array}$ & $\begin{array}{l}\text { Interviews were } \\
\text { conducted with } 20 \\
\text { registered nurses. } \\
\text { Thematic data analy- } \\
\text { sis was used to ana- } \\
\text { lyse the transcribed } \\
\text { interview data. }\end{array}$ & $\begin{array}{l}\text { Five themes emerged: listen- } \\
\text { ing to the patient, engaging } \\
\text { the patient, relinquishing } \\
\text { some responsibility, sharing } \\
\text { power, and partnering with } \\
\text { patients. In addition, hinder- } \\
\text { ing and facilitating factors to } \\
\text { participation were identified, } \\
\text { including patient desire to } \\
\text { take on a passive role and } \\
\text { lack of teamwork, which par- } \\
\text { ticipants understood would } \\
\text { enhance patient safety. } \\
\text { Patient participation was } \\
\text { hindered by medical jargon } \\
\text { during the ward round; there } \\
\text { was a risk of staff talking } \\
\text { above patient comprehen- } \\
\text { sion, which was sometimes } \\
\text { inevitable at the patient's } \\
\text { bedside. }\end{array}$ & $\mathrm{I} / \mathrm{K}$ \\
\hline $\begin{array}{l}\text { Sharma, Klocke } \\
2014 \\
\text { USA }\end{array}$ & $\begin{array}{l}\text { To study and improve } \\
\text { the perceived commu- } \\
\text { nication and interpro- } \\
\text { fessional care provided } \\
\text { by medical providers } \\
\text { and nursing staff. }\end{array}$ & $\begin{array}{l}\text { Attitudes of nursing } \\
\text { staff toward interpro- } \\
\text { fessional in-patient- } \\
\text { centred rounding }\end{array}$ & $\begin{array}{l}\text { We surveyed attitudes } \\
\text { of nursing staff before } \\
\text { and after four-month } \\
\text { implementation of } \\
\text { a patient-centred } \\
\text { physician-nurse } \\
\text { rounding process for } \\
\text { in-patients. }\end{array}$ & $\begin{array}{l}\text { Compared with baseline pre- } \\
\text { rounding data, nursing staff } \\
\text { satisfaction related to the } \\
\text { communication and round- } \\
\text { ing by hospitalist providers } \\
\text { significantly improved after } \\
\text { the patient-centred in-patient } \\
\text { rounding model was imple- } \\
\text { mented. Nursing workflow, } \\
\text { nurses' perceptions of value } \\
\text { as a team member, and their } \\
\text { job satisfaction were also } \\
\text { positively impacted. }\end{array}$ & $\mathrm{II} / \mathrm{K}$ \\
\hline
\end{tabular}


Table 4/3. Framework for the review, including quality control.

\begin{tabular}{|c|c|c|c|c|c|}
\hline $\begin{array}{l}\text { AUTHORS } \\
\text { YEAR } \\
\text { COUNTRY }\end{array}$ & AlM & TITLE & METHODS & RESULTS & $\begin{array}{l}\text { QUALITY/ } \\
\text { TYPE OF } \\
\text { STUDY }\end{array}$ \\
\hline $\begin{array}{l}\text { Wolf, Moore, } \\
\text { Lydahl, Naldemirci, } \\
\text { Elam, Britten } \\
2017 \\
\text { Sweden }\end{array}$ & $\begin{array}{l}\text { To explore the reali- } \\
\text { ties of partnership as } \\
\text { perceived by patients } \\
\text { and health profession- } \\
\text { als in everyday PCC } \\
\text { practice. }\end{array}$ & $\begin{array}{l}\text { The realities of part- } \\
\text { nership in person-cen- } \\
\text { tred care: a qualitative } \\
\text { interview study with } \\
\text { patients and profes- } \\
\text { sionals }\end{array}$ & $\begin{array}{l}\text { Qualitative study } \\
\text { employing a thematic } \\
\text { analysis of semi-struc- } \\
\text { tured interviews with } \\
\text { professionals and } \\
\text { patients. }\end{array}$ & $\begin{array}{l}\text { Our findings identified } \\
\text { both informal and formal } \\
\text { aspects of partnership that } \\
\text { patients felt listened to and } \\
\text { informed. They were content } \\
\text { to ask questions and felt less } \\
\text { involved in care planning, } \\
\text { documentation, or exploring } \\
\text { lifestyle goals. }\end{array}$ & $\mathrm{I} / \mathrm{K}$ \\
\hline $\begin{array}{l}\text { Alharbi, Olsson, } \\
\text { Ekman, Carlström } \\
2014 \\
\text { Sweden }\end{array}$ & $\begin{array}{l}\text { To measure the } \\
\text { effect of organisa- } \\
\text { tional culture on } \\
\text { health outcomes of } \\
\text { patients } 3 \text { months after } \\
\text { discharge. }\end{array}$ & $\begin{array}{l}\text { The impact of } \\
\text { organisational culture } \\
\text { on the outcome of } \\
\text { hospital care: after } \\
\text { the implementation of } \\
\text { person-centred care }\end{array}$ & $\begin{array}{l}\text { A quantitative study } \\
\text { using Organisational } \\
\text { Values Questionnaire } \\
\text { (OVQ) and a health- } \\
\text { related quality of life } \\
\text { instrument (EQ-5D). }\end{array}$ & $\begin{array}{l}\text { The results tentatively indi- } \\
\text { cated an association between } \\
\text { an organisational culture and } \\
\text { patients' health-related qual- } \\
\text { ity of life. Our results showed } \\
\text { that it could be hindering } \\
\text { instead of helping the new } \\
\text { health care model achieve its } \\
\text { objectives. }\end{array}$ & $\mathrm{II} / \mathrm{P}$ \\
\hline $\begin{array}{l}\text { Gachoud, Albert, } \\
\text { Kuper, Stroud, } \\
\text { Reeves } \\
2012 \\
\text { Canada }\end{array}$ & $\begin{array}{l}\text { To explore how } \\
\text { "patient-centredness" } \\
\text { is operationalised in } \\
\text { the work life of those } \\
\text { professionals. }\end{array}$ & $\begin{array}{l}\text { Meanings and percep- } \\
\text { tion of patient-centred- } \\
\text { ness in social work, } \\
\text { nursing and medicine: } \\
\text { a comparative study }\end{array}$ & $\begin{array}{l}\text { Semi-structured inter- } \\
\text { views were employed } \\
\text { because they gener- } \\
\text { ate understanding of } \\
\text { the meanings differ- } \\
\text { ent individuals have of } \\
\text { their real-life world. }\end{array}$ & $\begin{array}{l}\text { The analysis generated three } \\
\text { main themes: "Definition of } \\
\text { PCP"; "Value given to PCP"; } \\
\text { and "PCP and collabora- } \\
\text { tion". All the themes gave } \\
\text { a specific perspective on } \\
\text { patient-centred in practice } \\
\text { (PCP) and are presented } \\
\text { below. }\end{array}$ & $\mathrm{II} / \mathrm{K}$ \\
\hline $\begin{array}{l}\text { McMurray, Chaboy- } \\
\text { er, Wallis, Johnson, } \\
\text { Gehrke } \\
2011 \\
\text { Australia }\end{array}$ & $\begin{array}{l}\text { To examine patients' } \\
\text { perspectives of } \\
\text { participation in shift-to- } \\
\text { shift bedside nursing } \\
\text { handover. }\end{array}$ & $\begin{array}{l}\text { Patients'perspec-tives } \\
\text { of bedside nursing } \\
\text { handover }\end{array}$ & $\begin{array}{l}\text { A descriptive case } \\
\text { study was conducted. } \\
\text { Data were analysed } \\
\text { using thematic con- } \\
\text { tent analysis. }\end{array}$ & $\begin{array}{l}\text { Four themes emerged from } \\
\text { the analysis: patients appre- } \\
\text { ciated being acknowledged } \\
\text { as partners in their care; they } \\
\text { viewed bedside handover as } \\
\text { an opportunity to amend any } \\
\text { inaccuracies in the informa- } \\
\text { tion being communicated; } \\
\text { some preferred passive en- } \\
\text { gagement rather than being } \\
\text { fully engaged in the hando- } \\
\text { ver; most patients appreci- } \\
\text { ated the inclusive approach } \\
\text { of handover as nurse-patient } \\
\text { interaction. }\end{array}$ & $\mathrm{I} / \mathrm{K}$ \\
\hline $\begin{array}{l}\text { Broderick, Coffey } \\
2012 \\
\text { Ireland }\end{array}$ & $\begin{array}{l}\text { To explore nursing } \\
\text { documentation in } \\
\text { long-term care, to } \\
\text { determine whether it } \\
\text { reflected a person- } \\
\text { centred approach to } \\
\text { care, and to describe } \\
\text { aspects of PCC as } \\
\text { they appeared in } \\
\text { nursing records. }\end{array}$ & $\begin{array}{l}\text { Person-centred care } \\
\text { in nursing documen- } \\
\text { tation. }\end{array}$ & $\begin{array}{l}\text { A qualitative descrip- } \\
\text { tive study using the } \\
\text { PCN framework as } \\
\text { the context through } \\
\text { which nursing assess- } \\
\text { ments and care plans } \\
\text { were explored. }\end{array}$ & $\begin{array}{l}\text { Findings indicated that } \\
\text { many nursing records were } \\
\text { incomplete, and documenta- } \\
\text { tion of information regarding } \\
\text { psychosocial aspects of } \\
\text { care was infrequent. There } \\
\text { was evidence that nurses } \\
\text { engaged with residents and } \\
\text { worked with their beliefs and } \\
\text { values. Nursing documen- } \\
\text { tation was not completed } \\
\text { in consultation with the } \\
\text { patient, and there was little } \\
\text { to suggest that patients were } \\
\text { involved in decisions related } \\
\text { to their care. }\end{array}$ & $\mathrm{I} / \mathrm{K}$ \\
\hline
\end{tabular}




\section{REFERENCES}

1. Smith MA. The Role of Shared Decision Making in Patient-Centred Care and Orthopaedics. Orthopedic nursing. 2016;35(3): 144-9.

2. Vaismoradi $M$, Jordan $S$, Kangasniemi M. Patien participation in patient safety and nursing input - a systematic review. Journal of clinical nursing. 2015;24(5-6):627-39.

3. Edberg A-K. Omvårdnadens grunder : en specialutgåva för sjuksköterskor. Lund: Studentlitteratur; 2010.

4. Papastavrou E, Efstathiou G, Tsangari H, Karlou C Patiraki $E$, Jarosova $D$, et al. Patients' decisional control over care: a cross-national comparison from both the patients' and nurses' points of view. Scandinavian journal of caring sciences. 2016;30(1):26-36

5. Arvidsdotter T, Marklund B, Taft C. Effects of an integrative treatment, therapeutic acupuncture and conventional treatment in alleviating psychological distress in primary care patients--a pragmatic randomized controlled trial. BMC complementary and alternative medicine. 2013;13:308.

6. Dudas K, Olsson LE, Wolf A, Swedberg K, Taft C, Schaufelberger $M$, et al. Uncertainty in illness among patients with chronic heart failure is less in personcentred care than in usual care. European journal of cardiovascular nursing : journal of the Working Group on Cardiovascular Nursing of the European Society of Cardiology. 2013;12(6):521-8.

7. Feldthusen C, Dean E, Forsblad-d'Elia H, Mannerkorpi K. Effects of Person-Centred Physical Therapy on Fatigue-Related Variables in Persons With Rheumatoid Arthritis: A Randomized Controlled Trial. Archives of physical medicine and rehabilitation. 2016;97(1):26-36

8. Hansson E, Carlstrom E, Olsson LE, Nyman J, Koinberg I. Can a person-centred-care intervention improve health-related quality of life in patients with head and neck cancer? A randomized, controlled study. BMC nursing. 2017;16:9.

9. Socialdepartementet. Hälso- och sjukvårdslag (2017:30) Stockholm: Sveriges riksdag; 2017 [Available from: https://www.riksdagen.se/sv/ dokument-lagar/dokument/svensk-forfattningssamling/halso--och-sjukvardslag_sfs-2017-30.]

10. Socialdepartementet. Patientlag (2014:821) Stockholm: Sveriges Riksdag; 2014 [Available from https://www.riksdagen.se/sv/dokument-lagar/ dokument/svensk-forfattningssamling/patientlag-2014821 sfs-2014-821.]

11. Socialdepartementet. Socialtjänstlag (2001:453) Stockholm: Sveriges Riksdag; 2001 [Available from: https://www.riksdagen.se/sv/dokument-lagar/ dokument/svensk-forfattningssamling/socialtjanstlag-2001453_sfs-2001-453.]

12. Socialstyrelsen. SOSFS 2011:9 Ledningssystem för systematiskt kvalitetsarbete, 2011 Stockholm: Socialstyrelsen; [Available from: https://www. socialstyrelsen.se/publikationer2011/2011-6-38.]

13. Wilson J. Breaking down barriers to patient engagement. British journal of nursing (Mark Allen Publish ing). 2010;19(8):473.
14. Suter E, Arndt J, Arthur N, Parboosingh J, Taylor E, Deutschlander $S$. Role understanding and effective communication as core competencies for collaborative practice. Journal of interprofessional care. 2009;23(1):41-51.

15. Robinson JH, Callister LC, Berry JA, Dearing KA. Patient-centred care and adherence: definitions and applications to improve outcomes. Journal of the American Academy of Nurse Practitioners. 2008:20(12):600-7.

16. Kim HS. The nature of theoretical thinking in nursing. New York: Springer Pub. Co.; 2010.

17. Berwick DM. What 'patient-centred' should mean: confessions of an extremist. Health affairs (Project Hope). 2009;28(4):w555-65.

18. McCormack B. Person-centredness in gerontologica nursing: an ovenview of the literature. Journal of clinical nursing. 2004;13(3a):31-8.

19. Ekman I. Personcentrering inom hälso- och sjukvård : från filosofi till praktik [ ccccc] Stockholm: Liber 2014

20. Travelbee J. Interpersonal aspects of nursing 1971.

21. Dahlberg K, Ekman I. Vägen till patientens värld och personcentrerad vård : att bli lyssnad på och förstådd. Stockholm: Liber; 2017.

22. Caldwell K, Henshaw L, Taylor G. Developing a framework for critiquing health research: an early evaluation. Nurse education today. 2011;31(8):e1-7.

23. Berg A. Evidensbaserad omvårdnad vid behandling av personer med depressionssjukdomar. Stockholm: SBU; 1999.

24. Willman A, Stoltz P, Bahtsevani C. Evidensbaserad omvårdnad : en bro mellan forskning \& klinisk verksamhet. Lund: Studentlitteratur; 2011.

25. Bettany-Saltikov J, McSherry R. How to do a systematic literature review in nursing : a step-by-step guide. London: McGraw-Hill Education/Open University Press; 2016

26. Tobiano G, Marshall A, Bucknall T, Chaboyer W. Activities Patients and Nurses Undertake to Promote Patient Participation. Journal of nursing scholarship : an official publication of Sigma Theta Tau International Honor Society of Nursing. 2016;48(4):362-70.

27. Bolster D, Manias E. Person-centred interactions between nurses and patients during medication activities in an acute hospital setting: qualitative observation and interview study. International journal of nursing studies. 2010;47(2):154-65.

28. Oxelmark L, Ulin K, Chaboyer W, Bucknall T, Ringdal $M$. Registered Nurses' experiences of patient participation in hospital care: supporting and hindering factors patient participation in care. Scandinavian journal of caring sciences. 2017.

29. Alharbi TS, Carlstrom E, Ekman I, Jarneborn A Olsson LE. Experiences of person-centred care - patients' perceptions: qualitative study. BMC nursing. 2014; $13: 28$.

30. McMurray A, Chaboyer W, Wallis M, Johnson J, Gehrke T. Patients' perspectives of bedside nursing handover. Collegian (Royal College of Nursing, Australia). 2011;18(1):19-26.
31. Sharma U, Klocke D. Attitudes of nursing staff toward interprofessional in-patient-centred rounding. Journal of interprofessional care. 2014;28(5):475-7.

32. Broderick MC, Coffey A. Person-centred care in nursing documentation. International journal of older people nursing. 2013;8(4):309-18

33. Gachoud D, Albert M, Kuper A, Stroud L, Reeves S. Meanings and perceptions of patient-centredness in social work, nursing and medicine: a comparative study. Journal of interprofessional care. 2012;26(6):484-90

34. Jangland E, Gunningberg L. Improving patient participation in a challenging context: a 2-year evaluation study of an implementation project. Journal of nursing management. 2017;25(4):266-75

35. Alharbi TS, Olsson LE, Ekman I, Carlstrom E. The impact of organisational culture on the outcome of hospital care: after the implementation of personcentred care. Scandinavian journal of public health. 2014;42(1):104-10

36. Tobiano G, Bucknall $T$, Marshall A, Guinane J, Chaboyer W. Nurses' views of patient participation in nursing care. Journal of advanced nursing 2015;71(12):2741-52.

37. Svanstrom $R$, Andersson $S$, Rosen $H$, Berglund M Moving from theory to practice: experience of implementing a learning supporting model designed to increase patient involvement and autonomy in care. BMC research notes. 2016;9:361.

38. Sharp $S$, McAllister $M$, Broadbent $M$. The vital blend of clinical competence and compassion: How patients experience person-centred care. Contemporary nurse. 2016;52(2-3):300-12.

39. Wolf A, Moore L, Lydahl D, Naldemirci O, Elam M, Britten $N$. The realities of partnership in personcentred care: a qualitative interview study with patients and professionals. BMJ open. 2017;7(7):e016491

40. Abdelhadi N, Drach-Zahavy A. Promoting patien care: work engagement as a mediator between ward service climate and patient-centred care. Journal of advanced nursing. 2012;68(6):1276-87.

41. Tobiano G, Bucknall T, Sladdin I, Whitty JA, Chaboyer W. Patient participation in nursing bedside handover: A systematic mixed-methods review. International journal of nursing studies. 2018;77:243-

42. Nilsen P, Skagerstrom J, Ericsson C, Schildmeijer K. Patient participation for safer health care - interviews with physicians and nurses]. Lakartidningen. $2017 ; 114$. 